\title{
НАЦІОНАЛЬНИЙ ПІДРУЧНИК - ВАЖЛИВА СКЛАДОВА ОРГАНІЗАЦІЇ ПІДГОТОВКИ ФАХІВЦІВ У ВИЩИХ МЕДИЧНИХ ТА ФАРМАЦЕВТИЧНИХ НАВЧАЛЬНИХ ЗАКЛАДАХ
}

\author{
М. С. Осійчук, О. П. Волосовець, І. С. Вітенко, І. В. Мельник, М. О. Поліщук \\ Міністерство охорони здоров'я України, \\ ДУ “Центральний методичний кабінет з вищої медичної освіти МОЗ Украӥни”
}

\section{NATIONAL TEXTBOOK - AN IMPORTANT COMPONENT OF ORGANIZATION OF SPECIALISTS' TRAINING IN HIGHER MEDICAL AND PHARMACEUTICAL EDUCATIONAL INSTITUTIONS}

\author{
M. S. Osiychuk, O. P. Volosovets, I. S. Vitenko, I. V. Melnyk, M. O. Polishchuk \\ Ministry of Public Health of Ukraine, \\ SI "Central Methodical Cabinet on Higher Medical Education of MPH of Ukraine"
}

\begin{abstract}
У статті проведено аналіз забезпечення підручниками і посібниками студентів вищих медичних навчальних закладів України, запропоновано способи поліпшення навчально-методичного забезпечення навчального процесу, що є важливою передумовою покращення організації підготовки фахівців у ВМНЗ України.
\end{abstract}

The article adduces the analysis of providing with textbooks and manuals of students of higher medical educational institutions of Ukraine, offers the ways to improve the educational-methodological supply of educational process that is an important precondition of improvement of specialists' training organization in HMEI of Ukraine.

Вступ. Організація належної підготовки фахівців для медичної галузі неможлива без достатнього забезпечення дисциплін додипломної та післядипломної підготовки сучасними підручниками та посібниками, підготовленими відповідно до оновлених навчальних програм, новітніх здобутків світової та вітчизняної медичної науки [1-4].

Основна частина. У Плані реалізації завдань, визначених розпорядженням Кабінету Міністрів України від 27 серпня 2010 року № 1728 “Про затвердження плану заходів щодо розвитку вищої освіти на період до 2015 року”, видання навчальної літератури для вищих навчальних закладів, у тому числі на електронних носіях, $є$ одним із пріоритетних завдань.

Відповідно до наказу Державної інспекції навчальних закладів України від 04.07.2012 р. № 28-9 “Про затвердження програм державного інспектування вищих навчальних закладів”, показник нормативу забезпеченості студентів підручниками, навчальними посібниками, наявними у власній бібліотеці, за освітньокваліфікаційним рівнем “спеціаліст” становить 100\%. Окремо аналізується частка дисциплін, забезпечення яких навчальною літературою не перевищує 50 \% (у розрахунку 3 підручники на 1 студента).
Моніторинг забезпечення студентів сучасними підручниками та посібниками, виданими державною мовою на паперових носіях, протягом останніх п’яти років, який щорічно проводиться Центральним методичним кабінетом з вищої медичної освіти MO3 України, свідчить, що станом на 1 вересня 2012 року забезпечення підручниками студентів медичних факультетів вищих медичних навчальних закладів IV рівня акредитації MO3 України $є$ недостатнім і становить $37 \%$, посібниками - $39 \%$ (табл. 1).

Як свідчать результати моніторингу стану навчально-методичної роботи, проведеного на виконання наказу МОЗ України від 24.10.2012 p. № 834 "Про навчально-методичну діяльність вищих медичних та фармацевтичних навчальних закладів I - IV рівнів акредитації” у більшості вищих медичних навчальних закладів IV рівня акредитації МОЗ України, протягом осінньо-зимового семестру 2012 - 2013 навчального року наведені дані суттєво не змінились.

Разом $з$ тим слід зазначити, що зазначені показники є вищими за аналогічні у 2011 та 2010 роках, що свідчить про позитивні зрушення у забезпеченні студентів оновленими навчальними книгами, незважаючи на відсутність державного фінансування видання

() М. С. Осійчук, О. П. Волосовець, І. С. Вітенко та ін. 
Матеріали Х ювілейної Всеукраїнської навчально-наукової конференції з міжнародною участю

“Кредитно-модульна система організації навчального процесуу вищих медичних (фармацевтичному) навчальних закладах України на новому етапі"

Таблиця 1. Забезпечення підручниками і посібниками студентів ВМНЗ (державна мова, термін використання -5 років)

\begin{tabular}{|c|c|c|}
\hline Рік проведення обрахунків & Забезпечення підручниками (\%) & Забезпечення посібниками (\%) \\
\hline 2008 & 43 & 44 \\
\hline 2009 & 47 & 58 \\
\hline 2010 & 32 & 27 \\
\hline 2011 & 28 & 39 \\
\hline 2012 & 37 & \\
\hline
\end{tabular}

навчальної літератури для студентів-медиків та фармацевтів. Позитивне зрушення показників забез-

печення підручниками і посібниками має місце 3 усіх блоків навчальних дисциплін (табл. 2).

Таблиця 2. Забезпечення підручниками і посібниками по блоках дисциплін

\begin{tabular}{|l|c|c|c|}
\hline & 2010 & 2011 & 2012 \\
\hline \multicolumn{3}{|c|}{ Гуманітарні та соціально-економічні дисципліни } \\
\hline Підручники, \% & 16 & 17 & 32 \\
\hline Посібники, \% & 31 & 23 & 44 \\
\hline \multicolumn{2}{|c|}{ Природничо-наукові дисципліни } \\
\hline Підручники, \% & 43 & 33 & 42 \\
\hline Посібники, \% & 37 & 26 & 40 \\
\hline \multicolumn{7}{|c|}{ Професійно-орієнтовані дисципліни } \\
\hline Підручники, \% & 36 & 34 & 34 \\
\hline Посібники, \% & 30 & 31 & \\
\hline
\end{tabular}

Зростання зазначених показників у 2012 роціпорівняно 32010 - 2011 роками значною мірою обумовлено реалізацією наказу МО3 України від 22.06.2010 р. № 502 “Про затвердження робочих груп з питань підготовки національних підручників для студентів вищих навчальних закладів IV рівня акредитації, підпорядкованих MO3 України", яким було доручено провідним фахівцям ВМ(Ф)НЗ сформувати авторські колективи для підготовки базових підручників з усіх дисциплін діючих навчальних планів підготовки лікарів. Оскільки відповідно до чинного законодавства викладання у вищих навчальних закладах здійснюється українською мовою, у вказаному наказі базовий підручник названо національним.

Відповідно до наказу МОЗ України від 30.07.2012 p. № 579 "Про підготовку до початку 2012/2013 навчального року та організацію його проведення", за- вершити роботу щодо створення базових державних підручників та поліпшення забезпечення студентів сучасними необхідно було до 1 березня 2013 року.

Однак, зважаючи на певні економічні та організаційні труднощі, не всі авторські колективи натепер завершили роботу з написання підручників із відповідних дисциплін. Станом на 20.03.2013 р. підготовлено (видано або надано відповідні дозволи на видання з грифом МОЗ України) 75 підручників з переліку національних.

При цьому найбільша кількість фахівців, які брали участь у написанні національних (базових) підручників, є співробітниками Національного медичного університету імені О. О. Богомольця, Одеського національного медичного університету, Львівського національного медичного університету імені Данила Галицького (табл. 3).

Таблиця 3. Кількість фахівців, що є співавторами базових підручників

\begin{tabular}{|l|c|}
\hline \multicolumn{1}{|c|}{ Вищі медичні навчальні заклади } & Кількість фахівців \\
\hline ВДНЗ України “Буковинський державний медичний університет” (БДМУ) & $\mathbf{5}$ \\
\hline Вінницький національний медичний університет імені М. І. Пирогова (ВНМУ) & $\mathbf{7}$ \\
\hline ДЗ “Дніпропетровська медична академія Міністерства охорони здоров’я України” (ДМА) & $\mathbf{9}$ \\
\hline Донецький національний медичний університет ім. М. Горького (ДНМУ) & $\mathbf{6}$ \\
\hline Запорізький державний медичний університет (ЗДМУ) & $\mathbf{2}$ \\
\hline ДВНЗ “Івано-Франківський національний медичний університет” (ІФНМУ) & $\mathbf{8}$ \\
\hline ДУ “Кримський державний медичний університет імені С. І. Георгієвського” (КДМУ) & $\mathbf{3}$ \\
\hline ДЗ “Луганський державний медичний університет” (ЛДМУ) & $\mathbf{4}$ \\
\hline
\end{tabular}


Матеріали Х ювілейної Всеукраїнської навчально-наукової конференції з міжнародною участю “Кредитно-модульна система організації навчального процесуу вищих медичних (фармацевтичному) навчальних закладах Украӥни на новому етапі"

\begin{tabular}{|l|c|}
\multicolumn{1}{|c}{ Вищі медичні навчальні заклади } & Кількість фахівців \\
\hline \multicolumn{1}{|c|}{ Львівський національний медичний університет імені Данила Галицького (ЛНМУ) } & $\mathbf{1 3}$ \\
\hline Національний медичний університет імені О. О. Богомольця (НМУ) & $\mathbf{4 4}$ \\
\hline Одеський національний медичний університет (ОНМУ) & $\mathbf{1 4}$ \\
\hline ДВНЗ “Тернопільський державний медичний університет імені І. Я. Горбачевського \\
Міністерства охорони здоров’я України” (ТДМУ) & $\mathbf{6}$ \\
\hline ВДНЗ України “Українська медична стоматологічна академія” (УМСА) & $\mathbf{7}$ \\
\hline Харківський національний медичний університет (ХНМУ) & $\mathbf{9}$ \\
\hline
\end{tabular}

Серед виданих підручників блоку природничо-наукової підготовки необхідно відмітити базові:

- Анатомія людини (В. Г. Черкасов (НМУ), А. С. Головацький (Закарпатський ДУ); М. Р. Сапін, Я. І. Федонюк (ТДМУ), А. І. Парахін), виданий у 3-х т. 2010 р.;

- Біоорганічна хімія (Б. С. Зіменковський, В. А. Музиченко (ЛНМУ), виданий у 2010 р.;

- Гістологія, цитологія та ембріологія(О. Д. Луцик (ЛНМУ), А. Й. Іванова, К. С. Кабак, Ю. Б. Чайковський (НМУ), виданий у 2010 р.;

- Мікробіологія, вірусологія та імунологія (В. П. Широбоков (НМУ), В. В. Бобир, В. Г. Войцеховський та ін. (НМУ), Н. О. Виноград, В. В. Данілейченко (ЛНМУ), І. В. Дзюблик (НМАПО), С. І. Климнюк (ТДМУ), Е. 3. Коваль (Ін-т урологіі), В. П. Ковальчук (ВНМУ), Г. М. Кременчуцький(ДМА), Ю. Л. Криворутченко (КДМУ), В. В. Мінухін (ХНМУ), В. Г. Палій (ВНМУ), Й. М. Федечко (ЛНМУ), А. Я. Циганенко (ХНМУ), виданий у 2011 р.

Підготовлено підручники з більшості дисциплін блоку професійної підготовки, у тому числі:

- Фармакологія (І. С. Чекман (НМУ), В. Й. Кресюн (ОНМУ), В. В. Годован, І. І. Заморський (ІФНМУ), Г. К. Звягінцева (ХНМУ), виданий у 2011 р.;

- Акушерство і гінекологія. Кн. 1: Акушерство. Кн. 2: Гінекологія (В. І. Грищенко, М. О. Щербина, Л. В. Потапова, І. М. Щербина, М. Г. Грищенко та ін. (ХНМУ), Б. М. Венцківський, О. П. Гнатко (НМУ), виданий у 2011 р.;

- Анестезіологія та інтенсивна терапія (Ф. С. Глумчер, Л. П. Чепкий, В. Ф. Москаленко, Н. О. Волошина, С. О. Дубров, С. М. Ярославська (НМУ), Л. В. Усенко (ДМА), Р. О. Ткаченко (НМАПО), О. В. Царьов (ДДМА), виданий у 2010 р.;

- Внутрішня медицина (В. Г. Пєрєдєрій, С. М. Ткач (НМУ), виданий у 2010 р.;

- Інфекційні хвороби (О. А. Голубовська), виданий у 2012 p.;

- Основи екології (В. Г. Бардов (НМУ), В. І. Федоренко (ЛНМУ), надано гриф у 2012 р.;

- Соціальна медицина та організація охорони здоров’я (В. Ф. Москаленко, Т. С. Грузєва, О. П. Гульчій,
С. М. Зоріна, О. Г. Назарова, Л. О. Прус, А. П. Чуйко (НМУ), В. М. Лехан (ДМА), Першаген Юран, Каролінський університет (Швеція), Хернандес Роберт, Університет Алабами (США), виданий у 2010 р.;

- Хірургія (Л. Я. Ковальчук (ТДМУ), виданий у 2010 p.;

- Пропедевтика дитячої терапевтичної стоматології (Л. О. Хоменко, О. І. Остапко, Н. В. Біденко, С. Ф. Любарець, І. М. Голубєва, О. В. Савичук, В. І. Шматко, О. Ф. Кононович (НМУ), Н. І. Смоляр, Г. М. Солонько (ЛНМУ), виданий у 2011 р.;

- Терапевтична стоматологія (А. В. Борисенко, М. Ф. Данилевський, М. Ю. Антоненко та ін. (НМУ), виданий у 2010 р.;

- Хірургічна стоматологія (В. О. Маланчук (НМУ), О. С. Воловар, Я. А. Кульбашна), виданий у 2011 р.

Підготовлено 16 базових підручників для слухачів закладів (факультетів) післядипломної освіти, зокрема:

- Акушерство та гінекологія (В. М. Запорожан і співавтори), надано гриф у 2012 р.;

- Анестезіологія та інтенсивна терапія (I. П. Шлапак (НМАПО), надано гриф у 2012 р.;

- Дитяча імунологія (Л. І. Чернишова, А. П. Волоха, Д. В. Самарін та ін. (НМАПО), надано гриф у 2012 р.;

- Дитяча онкологія (О. С. Дудніченко, Г. І. Клімнюк (ХМАПО), надано гриф у 2012 р.;

- Педіатрія (В. В. Бережний (НМАПО), надано грифу 2012 р.;

- Підліткова терапія (Л. К. Пархоменко (ХМАПО), надано гриф у 2012 р.;

- Пульмонологія та фтизіатрія (Ю. І. Фещенко, В. П. Мельник, І. Г. Ільницький (ЛНМУ), видано у 2011 p.

Частина підготовлених рукописів подана до Центрального методичного кабінету з вищої медичної освіти MO3 України для представлення на розгляд Комісії з медицини (1201) науково-методичної ради 3 питань освіти Міністерства освіти і науки, молоді та спорту України, склад якої визначено наказом МОНмолодьспорту України від 25.11.2011p. № 1364 (голова президії - ректор Національної медичної академії післядипломної освіти імені П. Л. Шупика 
Ю. В. Вороненко, заступник голови - директор ДУ "Центральний методичний кабінет з вищої медичної освіти МОЗ України” І. С. Вітенко).

Як вже неодноразово Кабінетом наголошувалось, позитивні зрушення показників забезпечення студентів сучасними підручниками та посібниками можливі тільки за умови збільшення у навчальних закладах коштів, направлених на видання та закупівлю навчальної літератури $[2,4]$.

Як свідчать матеріали, надані ЦМК з ВМО МОЗ України навчальними закладами, та результати моніторингу, проведеного у більшості навчальних закладів на виконання наказу МОЗ України від 24.10.2012 p. № 834 “Про навчально-методичну діяльність вищих медичних та фармацевтичних навчальних закладів I - IV рівнів акредитації”, найбільша кількість коштів на закупівлю навчальної літератури у 2010-2012 роках винайдено у Національному медичному університеті імені О. О. Богомольця, Луганському державному медичному університеті, Вінницькому національному медичному університеті імені М. І. Пирогова, Львівському національному медичному університеті імені Данила Галицького, Харківському національному медичному університеті (табл. 4).

Таблиця 4. Дані про кошти, направлені ВМНЗ на закупівлю навчальної літератури протягом 2008-2012 pp. (в грн)

\begin{tabular}{|c|c|c|c|c|c|}
\hline Назва навчального закладу & $2008 \mathrm{p}$. & $2009 \mathrm{p}$. & $2010 \mathrm{p}$. & $2011 \mathrm{p}$. & $2012 \mathrm{p.}$ \\
\hline БДМУ & 207692,20 & 16037,80 & 111238,00 & 177428,00 & 232405,00 \\
\hline ВНМУ & 422791,21 & 138400,00 & 206633,04 & 489553,80 & 750741,80 \\
\hline ДМА & 247774,30 & 130492,91 & 251369,10 & 286058,00 & 241750,00 \\
\hline ДНМУ & 219264,00 & 306656,70 & 302996,70 & 310453,00 & 295388,00 \\
\hline ЗДМУ & 155671,99 & 382367,24 & 252727,80 & 287283,00 & 268480,00 \\
\hline ІФНМУ & 395690,00 & 240003,00 & 472693,14 & 111162,50 & 223787,01 \\
\hline КДМУ & 210201,49 & 31209,13 & 31248,74 & 56858,40 & 107649,00 \\
\hline ЛДМУ & 446017,28 & 564122,20 & 1196129,20 & 1093749,40 & 958861,53 \\
\hline ЛНМУ & 590433,00 & 174151,21 & 402120,40 & 295145,00 & 602818,00 \\
\hline НМУ & 1732674,6 & 808155,00 & 2189140,50 & 1988931,00 & 2804047,00 \\
\hline НФУ & 78564,00 & 79428,00 & 533385,23 & 924504,00 & 33618,00 \\
\hline ОНМУ & 315813,81 & 911133,52 & 289012,04 & 327044,25 & 252267,00 \\
\hline ТДМУ & 190087,00 & 140606,60 & 158751,00 & 196860,00 & 203329,00 \\
\hline УМСА & 384769,41 & 98930,00 & 223600,00 & 250565,00 & 349444,00 \\
\hline ХНМУ & 47450,00 & 204136,50 & 314462,50 & 399270,00 & 615165,00 \\
\hline
\end{tabular}

При цьому у 2012 році середній показник коштів, направлених на придбання навчальних книг українською мовою, з розрахунку на одного студента найбільший у Національному медичному університеті імені О. О. Богомольця, Луганському державному медичному університеті, Львівському національно- му медичному університеті імені Данила Галицького, іноземними мовами - у Національному медичному університеті імені О. О. Богомольця, Українській медичній стоматологічній академії, Донецькому національному медичному університеті, Дніпропетровській медичній академії МОЗ України (табл. 5).

Таблиця 5. Кошти на закупівлю навчальної літератури (на одного студента) у 2011-2012 pp.

\begin{tabular}{|c|c|c|c|c|c|c|}
\hline \multirow{2}{*}{ ВМНЗ } & \multicolumn{2}{|c|}{ Українською } & \multicolumn{2}{c|}{ Російською } & \multicolumn{2}{c|}{ Іноземною } \\
\cline { 2 - 7 } & 2011 & 2012 & 2011 & 2012 & 2011 & 2012 \\
\hline БДМУ & 44,01 & 41,86 & - & - & 45,77 & 108,55 \\
\hline ВНМУ & 39,60 & 80,80 & 14,10 & 22,60 & 22,00 & 11,00 \\
\hline ДМА & 50,58 & 35,39 & 44,21 & 63,76 & 486,86 & 260,28 \\
\hline ДНМУ & 36,00 & 29,00 & 98,00 & 46,00 & 145,00 & 192,00 \\
\hline ЗДМУ & 48,61 & 41,60 & 46,70 & 28,20 & 18,00 & 37,90 \\
\hline ІФНМУ & 22,00 & 39,01 & 31,90 & 14,98 & 34,80 & 63,27 \\
\hline КДМУ & 74,86 & 43,13 & 2,97 & 16,58 & 20,31 & 49,33 \\
\hline ЛДМУ & 196,71 & 148,96 & 2379,53 & 117,27 & 241,51 & 140,22 \\
\hline ЛНМУ & 60,00 & 122,50 & 90,00 & 660,00 & 80,00 & 130,60 \\
\hline
\end{tabular}


Продовження табл. 5

\begin{tabular}{|c|c|c|c|c|c|c|}
\hline \multirow{2}{*}{ ВМНЗ } & \multicolumn{2}{|c|}{ Українською } & \multicolumn{2}{c|}{ Російською } & \multicolumn{2}{c|}{ Іноземною } \\
\cline { 2 - 7 } & 2011 & 2012 & 2011 & 2012 & 2011 & 2012 \\
\hline НМУ & 180,20 & 208,09 & 282,91 & 473,82 & 283,59 & 802,63 \\
\hline НФУ & 43,83 & 4,38 & 71,03 & 0,58 & 1308,77 & - \\
\hline ОНМУ & 53,43 & 50,30 & 43,89 & 31,90 & 144,49 & 67,20 \\
\hline ТДМУ & 59,37 & 50,24 & 120,96 & 185,90 & 31,24 & 57,40 \\
\hline УМСА & 63,50 & 81,70 & 63,01 & 97,76 & 165,66 & 290,41 \\
\hline ХНМУ & 85,66 & 51,25 & 30,39 & 222,70 & 82,57 & 157,43 \\
\hline
\end{tabular}

Найбілышу кількість коштів на видання навчальної літератури виділено у Національному фармацевтичному університеті, Одеському національному медичному університеті, Львівському національному університеті імені Данила Галицького, Запорізькому державному медичному університеті. Переважна кількість коштів направлена на видання книг державною мовою (виключення - Кримський державний медичний університет) (табл. 6).

Таблиця 6. Дані про кошти, направлені ВМНЗ на видання навчальної літератури протягом 2008-2012 рр. (в грн)

\begin{tabular}{|c|c|c|c|c|}
\hline \multirow{2}{*}{$\begin{array}{c}\text { Назва } \\
\text { навчального } \\
\text { закладу }\end{array}$} & \multicolumn{4}{|c|}{ Направлено на видання навчальної літератури протягом 2012 р. } \\
\hline & $\begin{array}{l}\text { загальна } \\
\text { сума (грн) }\end{array}$ & $\begin{array}{c}\text { українською мовою } \\
(\%)\end{array}$ & $\begin{array}{c}\text { російською мовою } \\
(\%)\end{array}$ & $\begin{array}{c}\text { іноземною мовою } \\
(\%)\end{array}$ \\
\hline БДМУ & 50461,00 & 64,3 & - & 35,7 \\
\hline BHMY & 129123,43 & 67,4 & 16,7 & 15,9 \\
\hline ДМА & 96800,00 & 59,8 & 32,2 & 8,0 \\
\hline ДНМУ & 34471,00 & 49 & 38 & 13 \\
\hline ЗДМУ & 294496,00 & 45 & 40 & 15 \\
\hline ІФНМУ & 166995,33 & 75,0 & 5,0 & 20,0 \\
\hline КДМУ & 5023 & 28,73 & 52,38 & 18,89 \\
\hline ЛДМУ & 20872,71 & 43,62 & 26,44 & 29,94 \\
\hline ЛНМУ & 361031,00 & 89,98 & 0,21 & 9,81 \\
\hline HMY & 3068400,00 & 85,8 & 12,1 & 2,1 \\
\hline НФУ & 636965,00 & 55,1 & 2,1 & 42,8 \\
\hline OHМУ & 512000,00 & 62,0 & 33,85 & 4,15 \\
\hline ТДМУ & 178857,00 & 75,8 & - & 24,2 \\
\hline УMCA & 96600,00 & 85,8 & 8,0 & 6,2 \\
\hline ХНМУ & 90946,27 & 46,66 & 26,10 & 27,24 \\
\hline
\end{tabular}

Необхідно додати, що поліпшення забезпечення студентів та лікарів-інтернів сучасними навчальними книгами можливе лише за умови посилення активності авторських колективів, сформованих з числа провідних фахівців ВМ(Ф)НЗ та закладів післядипломної освіти, щодо оновлення навчально-методичного забезпечення навчального процесу. Цьому сприяє затвердження нового переліку опорних кафедр на базі вищих медичних (фармацевтичного) навчальних закладів IV рівня акредитації та закладів післядипломної освіти, затвердженого наказом МОЗ України від 23.08.2011 р. № 532. Створення міжкафедральних підручників, посібників, навчальних відеофільмів тощо $\epsilon$ одним із основних розділів роботи кафедри як опорної відповідно до Примірного положення про опорну кафедру, затвердженого наказом МО3 України від 26.02.2003 р. № 86 “Про затвердження Примірного положення про опорну кафедру і переліку опорних кафедр вищих медичних (фармацевтичного) навчальних закладів III - IV рівнів акредитації та закладів післядипломної освіти МОЗ України", зі змінами, внесеними наказом МОЗ України від 23.08.2011 p. № 532 .

За результатами моніторингу стану навчально-методичної роботи, проведеного на виконання зазначеного вище наказу МО3 України від 24.10.2012 p. № 834, у більшості навчальних закладів моніторингова група МО3 України з метою поліпшення організації навчально-методичної роботи та якості підготовки спеціалістів пропонувала поліпшити забезпе- 
чення студентів підручниками (посібниками) з грифами МОЗ України та МОН України, виданими протягом останніх 5-ти років, здійснювати першочергово закупівлю (видання) підручників відповідно до Переліку національних підручників, підготовленого на виконання наказу МО3 України від 22.06.2010 p. № 502, а також активізувати роботу авторських колективів викладачів навчальних закладів, перш за все опорних кафедр, для створення сучасних підручників і навчальних посібників, у тому числі на електронних носіях.

Висновок. Поліпшення навчально-методичного забезпечення студентів-медиків та фармацевтів, у тому числі сучасними базовими підручниками, можливе за умови посилення творчої активності авторських колективів викладачів навчальних закладів, зростання коштів, направлених навчальними закладами на закупівлю та видання навчальної літератури.

\section{Література}

1. Інтеграція додипломної та післядипломної підготовки лікарів та провізорів - вимога успішної реалізації реформ у сфері охорони здоров'я / Р. О. Моісеєнко, О. К. Толстанов, В. В. Вороненко [та ін.] // Впровадження нових технологій за кредитно-модульної системи організації навчального процесу у ВМ(Ф)НЗ III-IV рівнів акредитації: м-ли Всеукр. наук. навч.-метод. конф., присвяченої 55-річчю Тернопільського державного медичного університету імені І. Я. Горбачевського МОЗ України. - Тернопіль : Укрмедкнига, 2012.-С. 1-4.

2. Створення сучасного підручника - запорука підвищення ефективності навчального процесу / О. П. Волосовець, Ю. С. П'ятницький, І. С. Вітенко, І. В. Мельник // Нові напрямки впровадження кредитно-модульної системи організації навчального процесу у вищих медичних і фармацевтичному навчальних закладах України III-IV рівнів акредитації : м-ли Всеукр. наук. навч.-метод. конф. - Тер-

нопіль : Укрмедкнига, 2011.-С. 14-18.

3. Вітенко I. С. Вимоги до сучасного українського підручника / І. С. Вітенко, І. В. Мельник, С. В. Штанько // Нові напрямки впровадження кредитно-модульної системи організації навчального процесу у вищих медичних і фармацевтичному навчальних закладах України III-IV рівнів акредитації : м-ли Всеукр. наук. навч.-метод. конф. - Тернопіль : Укрмедкнига, 2011.-С. 18-19.

4. Основні проблеми покращання забезпечення студентівмедиків сучасною навчально-методичною літературою / І. С. Вітенко, І. В. Мельник, С. В. Штанько, Л. Г. Варнавська // Впровадження нових технологій за кредитно-модульної системи організації навчального процесу у ВМ(Ф)НЗ IIIIV рівнів акредитації : м-ли Всеукр. наук. навч.-метод. конф., присвяченої 55-річчю Тернопільського державного медичного університету імені І. Я. Горбачевського МОЗ України. - Тернопіль : Укрмедкнига, 2012. -С. 19-23. 